\title{
Development of Learning Tools with a Scientific Approach to Improve Mathematical Communication Skills and Student Activities of Smk Buana Bahari Medan
}

\author{
Nanda Amalia HST ${ }^{1} \quad$ Edi Syahputra ${ }^{2} \quad$ Edy Surya $^{2}$ \\ 1.Students of Mathematics Education, State University of Medan, Jl. Williem Iskandar Psr. V Medan Estate, \\ 20221, North Sumatra, Indonesia \\ 2.Lecturer at Medan State University, J1. Williem Iskandar Psr. V Medan Estate, 20221, North Sumatra, \\ Indonesia
}

\begin{abstract}
This study aims to: 1) Describe the learning tools with a scientific approach that meets the valid, practical and effective criteria; 2) Describe the improvement of mathematical communication skills by using learning tools with a scientific approach that was developed; 3) Describe the increase in student activity by using learning tools with a scientific approach that was developed. This research is a development study conducted in two stages. The learning tools that resulted from this study were: Student Worksheet (LKPD). From the results of the Implementation and evaluation stage, it was obtained: 1) the learning tools with the developed scientific approach had fulfilled the valid, practical, and effective criteria in terms of each criterion; 2) there is an increase in students mathematical communication skills by using learning tools with a scientific approach developed at the implementation stage to obtain an average pretest value of 67.66 and a posttest value of 74.75 , and an increase in the evaluation stage with an average pretest value of 71.25 and posttest value $82.5 ; 3$ ) there is an increase in student activity by using learning tools with a scientific approach developed at the implementation stage to obtain an average of $50.02 \%$ and an increase in evaluation with an average of $79.44 \%$.
\end{abstract}

Keywords: Development of Learning Tools, ADDIE Model, Scientific, Mathematical Communication Skills, Student Activities

DOI: $10.7176 / \mathrm{JEP} / 10-35-05$

Publication date: December $31^{\text {st }} 2019$

\section{Introduction}

To achieve the goal of national education, it is pursued through formal and non-formal education channels. The role of teachers is demanded to improve the quality of education of the Indonesian people. Improving the quality of educational science at the level of primary and secondary education is carried out in all groups of science and technology subjects, one of these subjects is mathematics. Mathematics is an object of study that requires thinking. In learning mathematics, mathematical thinking ability is needed, namely the ability to carry out activities and processes or mathematical tasks (Syahbana) [1].

Human knowledge about mathematics has an important role in human civilization, so mathematics is a field of study that is always taught at every level of education at school. Given mathematics plays a very important role in human survival so many experts and practitioners of mathematics education are always trying to develop student knowledge about mathematics. As stated by Cockcroft (Sadiq) [2] "it would be very difficult - perhaps impossible - to live a normal life in very many parts of the world in the twentieth century without making use of mathematics of some kind", it would be very difficult or it is not possible for someone to live in this part of the earth in the 20th century without the slightest use of mathematics.

One of the life skills that needs to be developed through the education process is communication skills. Baroody (in Ansari) [3] mentions:

There are at least two important reasons why communication in mathematics needs to be developed among students. First, mathematics as language, means that mathematics is not just a tool to help thinking, a tool for finding patterns, solving problems or drawing conclusions, but mathematics is also a valuable tool for communicating ideas clearly, precisely and careful. Second, mathematics learning as social activity means as a social activity in learning mathematics, mathematics is also a vehicle for interaction between students and also communication between teacher and students.

Mathematical communication is one of the goals of mathematics learning and is one of the competency standards for graduate school students from primary to secondary education as set out in the Content Standards for Primary and Secondary Schools, Competency Standards and Basic Competencies and 2013 Curriculum Basic Competencies (Kemendikbud) [4] in the field of mathematics which is presented in full as follows: (1) Understanding mathematical concepts, explaining the interrelationships between concepts and applying concepts or algorithms, flexibly, accurately, efficiently, and precisely in problem solving. (2) Using reasoning on patterns 
and traits, carrying out mathematical manipulations in making generalizations, compiling evidence, or explaining mathematical ideas and statements. (3) Solve problems that include the ability to understand problems, design mathematical models, solve models and interpret the solutions obtained. (4) Communicate ideas with symbols, tables, diagrams or other media to clarify the situation or problem. (5) Having an attitude of appreciating the usefulness of mathematics in life, namely having curiosity, attention, and interest in learning mathematics.

Mathematical communication skills will play an effective role when the teacher conditions students to listen actively (listen actively) as they speak. Therefore changing the view of learning from teacher teaching to students, learning must already be the main focus in every learning activity. Mathematical communication skills in learning mathematics are very important to note. This is because through mathematical communication students can organize and think mathematically both verbally and in writing, besides that the response or communication between students can occur in the learning process.

The importance of these mathematical communication skills is not yet relevant to the reality of the Buana Bahari Vocational School in Medan. Based on the questions given to students, the conclusion is that the students' mathematical communication skills are still low. Because students' mathematical communication skills according to NCTM (Mahmudi) [5] can be seen from: (1) The ability to express mathematical ideas through oral, written, and demonstrate and visualize them. (2) The ability to understand, interpret, and evaluate Math ideas both verbally and in other visual forms. (3) The ability to use mathematical terms, notations and structures to present ideas, describe relationships and models of situations.

The lack of students' mathematical communication is also influenced by student activities. In the process of learning student activities are things that really need to be considered because in principle learning is doing or known as the motto of learning by doing. Doing to change behavior means to do something or activities. There is no learning if there is no activity because without the activity the learning process might not take place properly. That is why student activity is a principle or principle that is very important in the learning process.

Learning based on activities, according to Dave Meier (in Fadillaturahmi) [6] states active physical, mental, and emotional moves in the learning process, by utilizing all the potential senses that are owned as much as possible, and making the whole body or mind involved in the learning process. It can be concluded that the activity is the movement of all the potential that exists within a person / student actively, both physically, mentally and emotionally by looking at the mind in a learning process so that learning can run effectively as well. As for the physical, mental, and emotional movements expressed by Dave Meier (in Fadilaturrahmi) [6] is as follows:

(1) Physical Activity, which includes: (a) active in learning, (b) actively listening to teacher's explanations and directions, (c) active in asking questions, (d) actively answering teacher questions, and (e) carrying equipment requested by teacher (2) Mental Activities, which include: (a) preparing to take part in learning, (b) paying attention diligently to the teacher's directions and explanations, (c) being able to answer questions given by the teacher, and (d) enthusiasm for learning. (3) Emotional Activities, which include: (a) happy learning, (b) happy doing the assignments, (c) happy asking questions, (d) happy answering questions, and (e) happy group work in learning activities.

In enhancing student learning activities in the learning process required creative and active teacher participation in managing learning that is, teachers use learning strategies and methods that can increase students' physical, mental and emotional activities so that what is achieved in the learning process can be achieved properly.

After conducting a field review the data obtained from the scale of student learning activities that contain statements with answer choices always appear, often appear, sometimes appear, rarely appear and never appear, given to students of class XI SMK Pelayaran Buana Bahari Medan, amounting to 30 people . Based on the results of the scale of student learning activities obtained, it appears that almost all statements are answered occasionally, as well as the results of the interview again with the mathematics teacher who said that, "lack of enthusiasm of students in learning mathematics and self-confidence when working on problems". In addition, the lack of student activity is seen in the teaching and learning process. For example, students look cheating in working on problems and students are also seen asking their friends about the questions they are working on. This proves that some students lack motives and intentions within themselves and are less active in understanding mathematics, so the low learning activities of students are seen. The lack of mathematical communication skills and student learning activities that have been described above is natural if seen from learning activities in class which so far still use conventional learning, do not emphasize meaningful learning, teachers tend to be more active in giving, while students listen, take notes and do not give response to learning outcomes.

The use of appropriate learning tools in presenting learning is very influential on student achievement. To achieve the implementation of learning in schools must be supported by adequate facilities, besides that teachers also need skills in explaining the lessons so that they are easily understood by students, so that students' difficulties in the learning process can be overcome and students become more active.

Quality education is inseparable from the role of all parties, especially the role of teachers. The teacher is a very important component, because the successful implementation of the education process is very dependent on 
the teacher. Therefore, quality education efforts should start from improving teachers. One of the abilities that teachers must have is how to design a learning device that is suitable for the objectives to be achieved. A teacher will adjust learning so that learning goals can be achieved effectively.

Learning devices are a collection of learning resources arranged in such a way that students and teachers carry out learning activities, tests to measure learning outcomes and so on (Latief) [7]. Learning tools are very important for a teacher, because: (1) Learning devices provide guidance on what a teacher must do in class. Provide guidance in developing teaching techniques, (2) Learning tools as benchmarks, ie a professional teacher must evaluate the learning tools. This is important to improve the professionalism of a teacher, (3) Learning tools as an increase in professionalism, that is, a teacher's professionalism can be improved by means of learning tools means that learning tools are not only as administrative equipment, but as a medium for increasing professionalism, a teacher must develop and use devices learning so that teaching and learning activities can be successful.

Quality learning tools are learning devices that meet valid, practical and effective criteria. From Akker's statement (in Rochmad) [8] it was concluded that the quality criteria of a device are validity, practicality, and effectiveness. So that it can be stated that a quality device is one that meets all three aspects. according to Tati (Tati) [9] validity is obtained from the validation of the device by experts (experts) and colleagues that contain content validation (content), structure and language. Furthermore practicality means that learning tools can be applied by the teacher as planned and easily understood by students. While effectiveness is seen from the results of authentic assessments which include assessments of the learning process and learning outcomes.

The development of appropriate learning tools basically aims to create learning conditions that enable students to learn more actively and fun so that students can achieve optimal learning and achievement. But the reality is that at the Pelican Vocational School Buana Bahari Medan, not all teachers are able to realize the expected goals in learning mathematics. The teaching of mathematics that has been taught has only been emphasized on the ability of students to solve and work on math problems routinely, without planning and designing a device that is suitable for developing and activating student abilities.

From the cases in the field, it seems that the availability of learning tools is not in accordance with the above expectations. Conditions in the field of students only use LKPD published / circulated by certain institutions. This shows that teachers rarely make their own teaching materials such as LKPD, and students' ability tests. As we know, the existing LKPD does not reflect the LKPD that should be. LKPD usually only requires ordinary exercises without developing students' mathematical communication skills as expected.

From the criteria above, it seems clear that the 2013 curriculum places great importance on teacher preparation before implementing the teaching and learning process in the classroom, educative interactions in learning, and the use of learning methods that are able to inspire students to communicate. To answer this need, it is of course necessary to improve the quality and quality of education, both in terms of educators, existing facilities, learning tools and policies from the government that support the realization of educational needs in the field.

The implementation of the 2013 curriculum in learning with a scientific approach is a learning process that is designed so that students actively construct their concepts through the syntax of scientific learning, namely the stages of observing, formulating problems, proposing hypotheses, collecting data, analyzing data, drawing conclusions and communicating the concepts found. The scientific approach is intended to provide understanding to students in knowing, understanding various materials that information can come from anywhere, anytime, not dependent on information from the teacher. Therefore, the expected learning conditions created are directed to encourage students to find out from various observations, not just being told.

The reasons for choosing to develop learning tools based on a scientific approach to improve mathematical communication skills and student activities are because the scientific approach is able to lead students to achieve indicators of mathematical communication abilities and student activities. In accordance with the 2013 curriculum regulation on basic and secondary education process standards, the scientific approach refers to investigative techniques for something or some phenomenon or phenomenon, gaining new knowledge, correcting and integrating prior knowledge. This approach also utilizes a search method based on observable, empirical and measurable object evidence. Therefore, the scientific approach contains a series of activities (observing, asking, collecting data, associating, and communicating) in communicating mathematics. Many experts believe that a scientific approach can make students more active in communicating their knowledge, and can also encourage students to conduct investigations to find facts of a phenomenon or event.

From the description of these problems, researchers are interested in conducting research related to the mathematical abilities of the students and their relation to the existence of mathematical learning tools. So researchers are interested in researching about the development of learning tools with a Scientific Approach to Improve Mathematical Communication Skills and Student Activities at Sailing Vocational School Buana Bahari Medan.

\section{Research Methods}

This research is a development study of the device through the ADDIE model. This research has been carried out 
at SMK Pelayaran Buana Bahari Medan, located on Jl. Bilal Ujung Komplek Bilal Sentra Blok B No. 9 Medan. The time of the research was conducted in 2019. The subjects in this study were students of class XII namely XII Nautika-A and XII Nautika-B in the academic year 2019/2020, while the object in this study was a learning tool namely LKPD on statistical material.

\section{Results And Discussion}

3.1. Validity Analysis of Learning Tools Through Scientific Approach.

Validity analysis of learning tools with a scientific approach developed was seen from the assessment of experts / practitioners of learning devices consisting of 3 lecturers and 2 teachers of the field of study. The results of the validity of the experts are listed in table 1 below

Table 1. Summary of Learning Tools Validation Results

\begin{tabular}{|l|c|l|c|}
\hline No & Objects & rated Average total validity value & Validation Level \\
\hline 1 & Learning Implementation Plan (RPP) & 4,56 & \multirow{2}{*}{ Valid } \\
2 & Student Activity Sheet (LAS) & 4.5 & \\
\hline
\end{tabular}

In this table, the average total validity of each learning device is in the interval: $4 \leq \mathrm{Va}<5$. Based on the validity criteria, it can be said that the developed learning device is valid.

\subsection{Practical Analysis of Learning Tools through Scientific Approach in the Implementation Stage and Evaluation stage.}

Practicality of Learning Devices seen from the questionnaire of the implementation of learning devices. Learning devices with scientific approaches are said to be practical or easy to implement if the implementation of learning devices with scientific approaches is included in the high minimum category.

\subsubsection{The Implementation of Learning Tools at the Implementation Stage}

Achievement of the level of implementation of learning tools at the Implementation stage is included in the very high category which means the learning device is said to be practical or applicable. The average value of observing the feasibility of the learning kit for each meeting is shown in Table 2 below.

Table 2. Average - Observation Value of the Implementation of Learning Devices

\begin{tabular}{|l|l|l|l|l|l|l|}
\hline \multirow{2}{*}{ Overall Average of 2 meeting Observers } & \multicolumn{3}{|l|}{ Meeting } & \multirow{2}{*}{ Total Average } & \multirow{2}{*}{ Description } \\
\cline { 2 - 8 } & 1 & 2 & 3 & 4 & & \\
\hline Implemetastion Stage & 3.47 & 3.72 & 3.78 & 3.85 & 3.70 & High \\
\hline
\end{tabular}

The average total value of the four meetings was 3.70 , which was high $(3 \leq \bar{P} \leq 4)$.

3.2.2. Implementation of Learning Tools at the Evaluation stage

Achievement of the level of implementation of learning tools at the evaluation stage is included in the very high category which means the learning device is said to be practical or applicable. The average value of observing the feasibility of the learning kit for each meeting is shown in Table 3 below.

Table 3. Average Observation Value Of The Implementation Of Learning Tools

\begin{tabular}{|l|l|l|l|l|l|l|}
\hline \multirow{2}{*}{ No } & \multirow{2}{*}{ Aspects Observed and Rated } & \multicolumn{2}{|l|}{ Meeting } & \multirow{2}{*}{ Average } \\
\cline { 3 - 6 } & & I & II & III & IV & \\
\hline 1 & Implementation of Learning Implementation Plans (RPP) & 3.69 & 3.75 & 3.88 & 3.94 & 3.81 \\
\hline 2 & Work Performance of Students (LKPD) & 3.63 & 3.63 & 3.84 & 3.88 & 3.74 \\
\hline
\end{tabular}

Based on Table 3 it is found that, on average, 2 (two) observers for the evaluation stage of the meeting on the validity of the Student Worksheet (LKPD) were 3.74, which was at high $(3 \leq \bar{P} \leq 4)$

Based on the above results, the overall feasibility of learning tools is 3.78 , where if referred to the criteria for the learning equipment set out in chapter III, the average value of 3.78 is in the high category $(3 \leq \bar{P} \leq 4)$. Thus it can be concluded that, the learning tools developed are practical in terms of the implementation of the learning tools.

\subsection{Analysis of the Effectiveness of Learning Tools Through the Scientific Approach in the Implementation and Evaluation stages}

The effectiveness of the learning tools developed can be seen from the classical learning completeness of students; (2) students respond positively to the components of learning tools developed; and (3) the teacher's ability to manage learning is at least good enough. The following will be presented a discussion for each indicator in measuring the effectiveness of learning tools through a scientific approach.

3.3.1. Classical Learning Completeness of Students in Implementation Stage

The classical completeness results of students' mathematical communication skills can be seen in Table 4 below: 
Table 4. Classical Level of Mathematical Communication Skill

\begin{tabular}{|c|c|c|c|c|}
\hline \multirow{2}{*}{ Category } & Pretest & \multirow{2}{*}{$\begin{array}{c}\text { Percentage of } \\
\text { Classical } \\
\text { Completion }\end{array}$} & Posttest & \multirow{2}{*}{$\begin{array}{c}\text { Percentage of } \\
\text { Classical } \\
\text { Completion }\end{array}$} \\
\hline & amount of Students & & amount of Students & \\
\hline Completed & 16 & $53,33 \%$ & 22 & $73,33 \%$ \\
\hline Not Completed & 14 & $46,67 \%$ & 8 & $26,67 \%$ \\
\hline Amount & 30 & $100 \%$ & 30 & $100 \%$ \\
\hline
\end{tabular}

The percentage description of classical completeness criteria of students' mathematical communication skills is presented in Figure 1.

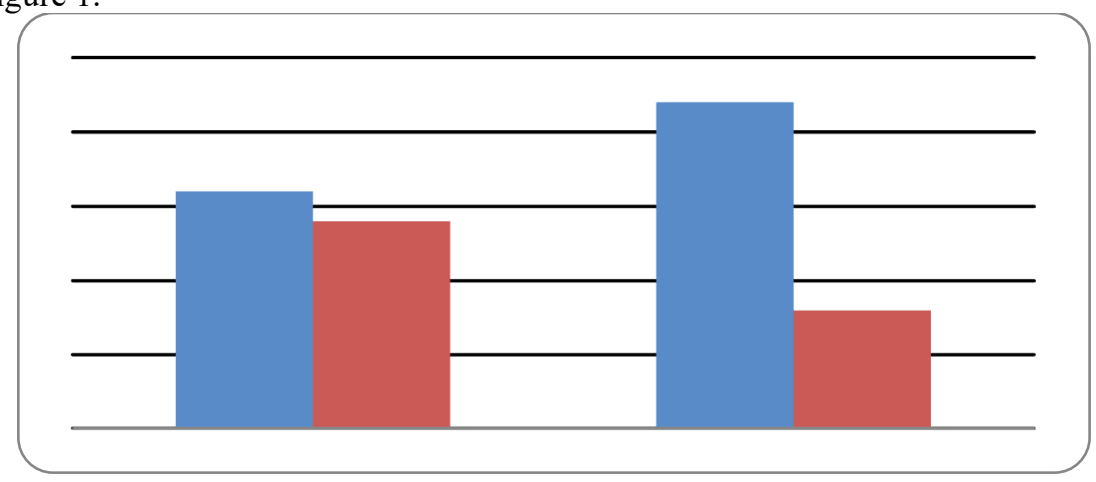

Figure 1. Percentage of Classical Completion Mathematical Communication Skills of Students in the Implementation stage

Based on the data in Table 4 and Figure 1, it can be seen that the classical completeness of the results of students 'mathematical communication abilities in pretest I trial is $53.33 \%$ while the classical completeness of students' mathematical communication abilities in posttest I trial is $73.33 \%$. In accordance with the completeness criteria of student learning outcomes in a classical way, which is a minimum of $75 \%$ of students who take the mathematical communication skills test is able to achieve a score of $\geq 75$. Thus, the results of the posttest mathematical communication skills have not met classical completeness because they only get a percentage of completeness $73.33 \%$. So it can be concluded that the application of learning tools through the development of LKPD that was developed did not meet the classical achievement criteria for completeness.

\subsubsection{Classical Learning Completeness of Students in Evaluation Stage}

The classical completeness results of students' mathematical communication skills can be seen in Table 5 below:

Table 5. Classical Mastery Level Mathematical Communication Capabilities

\begin{tabular}{|c|c|c|c|c|}
\hline \multirow{2}{*}{ Category } & Pretest & \multirow{2}{*}{$\begin{array}{c}\text { Percentage of } \\
\text { Classical } \\
\text { Completion }\end{array}$} & Posttest & \multirow{2}{*}{$\begin{array}{c}\text { Percentage of } \\
\text { Classical } \\
\text { Completion } \\
\end{array}$} \\
\hline & amount of Students & & amount of Students & \\
\hline Tuntas & 20 & $66,67 \%$ & 25 & $83,33 \%$ \\
\hline Tidak Tuntas & 10 & $33,33 \%$ & 5 & $16,67 \%$ \\
\hline Jumlah & 30 & $100 \%$ & 30 & $100 \%$ \\
\hline
\end{tabular}

The percentage description of classical completeness criteria of mathematical communication skills of students is presented in Figure 2.

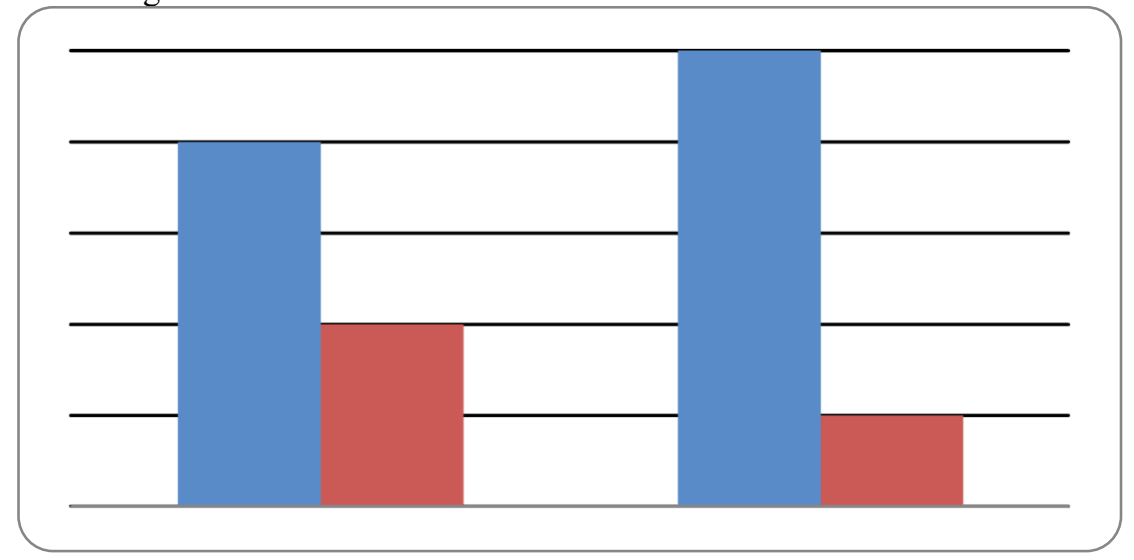

Figure 2. Percentage of Classical Mastery in Mathematical Communication Skills of Students 
Based on the data in Table 5 and Figure 2, it can be seen that the classical completeness of the results of students 'mathematical communication skills at the pretest is $66.67 \%$ while the classical completeness of the students' mathematical concept comprehension ability at the posttest is $83.33 \%$. In accordance with the completeness criteria of student learning outcomes in a classical way, which is at least $75 \%$ of students who take the mathematical communication ability test is able to achieve a score of $\geq 75$. Thus, the results of the posttest mathematical communication skills have met the classical completeness. So it can be concluded that the application of learning tools through the development of LKPD developed has met the criteria for completeness in classical achievement.

\subsection{Analysis of Improvement of Students' Mathematical Communication Skills}

The improvement of students' mathematical communication skills in the first trial will be seen through the N-Gain from the results of the pre-test and post-test mathematical communication skills. The results of N-Gain calculations on mathematical communication skills can be seen in the following table:

Table. 6 Summary of N-Gain Results in Mathematical Communication Skills

\begin{tabular}{|c|c|c|}
\hline $\boldsymbol{N}$-Gain & Interpretation & Number of Students \\
\hline $\mathrm{g} \leq 0,3$ & Low & 13 \\
\hline $0,3<\mathrm{g} \leq 0,7$ & Medium & 16 \\
\hline $\mathrm{g}>0,7$ & Height & 1 \\
\hline
\end{tabular}

Based on Table 6 above, it can be seen that 1 student received an N-Gain score in the range $>0$, or experienced an increase in mathematical communication skills with the "High" category. For students who experienced an increase in mathematical communication skills with the category "Medium" or received an N-Gain score of 0,3 $<\mathrm{g} \leq 0,7$ totaling 16 people and 13 people who received an $\mathrm{N}$-Gain score of $\mathrm{g} \leq 0,3$ or experienced an increase in communication skills mathematical with the category "Low". So, the average gain is obtained 0,255 in the low category.

While at the evaluation stage, improvement of students' mathematical communication skills can be seen in the following Table 7:

Table.7. Summary of N-Gain Results in Mathematical Communication Capabilities

\begin{tabular}{|c|c|c|}
\hline $\boldsymbol{N}$-Gain & Interpretation & Number of Students \\
\hline $\mathrm{g} \leq 0,3$ & Low & 17 \\
\hline $0,3<\mathrm{g} \leq 0,7$ & Medium & 10 \\
\hline $\mathrm{g}>0,7$ & Height & 3 \\
\hline
\end{tabular}

Based on Table 7 above it can be seen that 3 students received an N-Gain score in the range $>0,7$ or experienced an increase in mathematical communication skills in the "High" category. For students who have improved mathematical communication skills with the category "Medium" or get an N-Gain score of $0,3<\mathrm{g} \leq 0,7$ totaling 10 people and 17 people who received an N-Gain score of $g \leq 0,3$ with the category of "Low". So, the average gain is obtained 0,338 in the medium category.

\subsection{Description of Student Activity Questionnaire Results}

The description of student activities can be seen through the average student activity questionnaire for each indicator. For more details, see Table 8 below:

Table 8. Average Student Activity Scores for Each Indicator at Implementation

\begin{tabular}{|c|c|c|c|}
\hline No & Aspects of Student Activity & $\begin{array}{l}\text { Average Score } \\
\text { per Indicator }\end{array}$ & $\begin{array}{l}\text { Average } \\
\text { Total Score }\end{array}$ \\
\hline $\mathbf{A}$ & Observing & & \multirow{9}{*}{$50,02 \%$} \\
\hline 1 & Make a observation or investigation & $50 \%$ & \\
\hline 2 & $\begin{array}{l}\text { Active reading (for example with a pen in hand to underline or make } \\
\text { a small note or certain markings in the text) }\end{array}$ & $33,3 \%$ & \\
\hline 3 & $\begin{array}{l}\text { Active listening (showing response, eg smiling or laughing when } \\
\text { hearing funny things being conveyed, being amazed when hearing } \\
\text { something amazing, etc.) }\end{array}$ & $66,7 \%$ & \\
\hline B & Asking & & \\
\hline 1 & $\begin{array}{l}\text { Doing questions about information not understood from what was } \\
\text { observed }\end{array}$ & $16,7 \%$ & \\
\hline 2 & $\begin{array}{l}\text { Asking questions to get additional information about what was } \\
\text { observed }\end{array}$ & $33,3 \%$ & \\
\hline $\mathbf{C}$ & Experimentation / Exploration & & \\
\hline 1 & $\begin{array}{l}\text { Practicing (for example group testing concepts such as training with } \\
\text { questions) }\end{array}$ & 33,3 & \\
\hline
\end{tabular}




\begin{tabular}{|c|c|c|c|}
\hline No & Aspects of Student Activity & $\begin{array}{l}\text { Average Score } \\
\text { per Indicator }\end{array}$ & $\begin{array}{l}\text { Average } \\
\text { Total Score }\end{array}$ \\
\hline 2 & $\begin{array}{l}\text { Creative thinking (for example, trying to solve problems in exercises } \\
\text { that have variations that differ from the examples given) }\end{array}$ & $50 \%$ & \\
\hline 3 & $\begin{array}{l}\text { Critical thinking (for example being able to find irregularities, } \\
\text { weaknesses or mistakes made by others in solving problems or tasks) }\end{array}$ & $16,7 \%$ & \\
\hline 4 & Discuss, Express opinions & $66,7 \%$ & \\
\hline D & Associate / Manage information & & \\
\hline 1 & $\begin{array}{l}\text { Manage information that has been collected from activities carried } \\
\text { out by students }\end{array}$ & $50 \%$ & \\
\hline 2 & $\begin{array}{l}\text { Correcting mistakes or deficiencies in the process of activities } \\
\text { undertaken by students. }\end{array}$ & $66,7 \%$ & \\
\hline 3 & $\begin{array}{l}\text { Comment and conclude the results of the answers from the group } \\
\text { discussions that have been done. }\end{array}$ & $50 \%$ & \\
\hline $\mathbf{E}$ & Communicating & & \\
\hline 1 & Presentation of report & $83,3 \%$ & \\
\hline 2 & Concluding learning material with his own words & $83,3 \%$ & \\
\hline 3 & Displaying the work of & $66,7 \%$ & \\
\hline
\end{tabular}

Based on table 8 , it can be seen that the highest average score of indicators is at indicators 4 and 5 , which are associating, and communicating, followed by indicators of observing, experimenting, and asking questions. at $50.02 \%$. While the activity scores at the evaluation stage can be seen in table 9 below:

Table 9. Average Student Activity Scores for Each Indicator in the Evaluation stage

\begin{tabular}{|c|c|c|c|}
\hline No & Aspects of Student Activity & $\begin{array}{l}\text { Average Score } \\
\text { per Indicator }\end{array}$ & $\begin{array}{l}\text { Average } \\
\text { Total Score }\end{array}$ \\
\hline $\mathbf{A}$ & Observing & & \multirow{20}{*}{$79,44 \%$} \\
\hline 1 & Make a observation or investigation & $66,7 \%$ & \\
\hline 2 & $\begin{array}{l}\text { Active reading (for example with a pen in hand to underline or make } \\
\text { a small note or certain markings in the text) }\end{array}$ & $83,3 \%$ & \\
\hline 3 & $\begin{array}{l}\text { Active listening (showing response, eg smiling or laughing when } \\
\text { hearing funny things being conveyed, being amazed when hearing } \\
\text { something amazing, etc.) }\end{array}$ & $66,7 \%$ & \\
\hline B & Asking & & \\
\hline 1 & $\begin{array}{l}\text { Doing questions about information not understood from what was } \\
\text { observed }\end{array}$ & $66,7 \%$ & \\
\hline 2 & $\begin{array}{l}\text { Asking questions to get additional information about what was } \\
\text { observed }\end{array}$ & $83,3 \%$ & \\
\hline $\mathbf{C}$ & Experimentation / Exploration & & \\
\hline 1 & $\begin{array}{l}\text { Practicing (for example group testing concepts such as training with } \\
\text { questions) }\end{array}$ & $66,7 \%$ & \\
\hline 2 & $\begin{array}{l}\text { Creative thinking (for example, trying to solve problems in exercises } \\
\text { that have variations that differ from the examples given) }\end{array}$ & $66,7 \%$ & \\
\hline 3 & $\begin{array}{l}\text { Critical thinking (for example being able to find irregularities, } \\
\text { weaknesses or mistakes made by others in solving problems or tasks) }\end{array}$ & $50 \%$ & \\
\hline 4 & Discuss, Express opinions & $83,3 \%$ & \\
\hline $\mathbf{D}$ & Associate / Manage information & & \\
\hline 1 & $\begin{array}{l}\text { Manage information that has been collected from activities carried } \\
\text { out by students }\end{array}$ & $83,3 \%$ & \\
\hline 2 & $\begin{array}{l}\text { Correcting mistakes or deficiencies in the process of activities } \\
\text { undertaken by students. }\end{array}$ & $83,3 \%$ & \\
\hline 3 & $\begin{array}{l}\text { Comment and conclude the results of the answers from the group } \\
\text { discussions that have been done. }\end{array}$ & $100 \%$ & \\
\hline $\mathbf{E}$ & Communicating & & \\
\hline 1 & Presentation of report & $100 \%$ & \\
\hline 2 & Concluding learning material with his own words & $100 \%$ & \\
\hline 3 & Displaying the work of & $83,3 \%$ & \\
\hline
\end{tabular}

Based on table 9, it can be seen that the highest average score of indicators is on indicators 4 and 5, which are associating, and communicating, followed by indicators asking, observing, and experimenting. Then, the level 
of student activity seen from the overall average value of $79.44 \%$.

\section{Conclusion}

Based on the results of the analysis and discussion in this study, it can be concluded as follows:

1. The validity of the learning tools developed is included in the valid category with an average value of total RPP validity of 4.56 , LKPD of 4.50, items on the test of students' mathematical abilities and student questionnaires are also in the valid category.

2. Learning devices developed with a scientific approach have met practical criteria in terms of: (1) expert / practitioner assessments state that learning tools with a scientific approach that were developed can be used with little revision; and (2) the implementation of learning tools has reached a high category, namely at the implementation stage of 3.70 and at the evaluation stage of 3.76 .

3. Learning tools developed with scientific approaches that have met effective criteria. Effective criteria in terms of: students' mastery in classics has reached $83.33 \%$;

4. Increasing students' mathematical communication skills using learning tools with a scientific approach to statistical material is 10.5 while the increase in $\mathrm{N}$-Gain is 0.083 .

\section{References}

[1] Syahbana,Ali. 2012.Peningkatan Kemampuan Berpikir Kritis Matematis Siswa SMP Melalui Pendekatan Contextual Teaching And Learning, Jurnal Edumatica/Vol.2,No. 01, hal 45-57.

[2] Shadiq,2014. Pemecahan Masalah, Penalaran dan Komunikasi. Disampaikan pada Diklat Instruktur/Pengembang Matematika SMA Jenjang Dasar. Yokyakarta : Departemen Pendidikan Nasional.

[3] Ansari, B. 2016. Komunikasi Matematik :Strategi Berfikir dan Manajemen Belajar. Banda Aceh: PeNa

[4] Kemendikbud.2013. Konsep Pendekatan Scientific. Jakarta: Kementrian Pendidikan dan Kebudayaan.

[5] Mahmudi,Ali. 2009. Komunikasi Dalam Pembelajaran Matematika. Vol 8 No.1, Februari 2009. Hal 1-8.

[6] Fadhilaturrahmi. 2017.Penerapan Pendekatan Saintifik Untuk Meningkatkan Kemampuan Komunikasi Matematik Peserta Didik Di Sekolah Dasar. EduHumaniora: JurnalPendidikanDasar | ISSN 2085-1243 Vol. 9. No.2 Juli 2017 | Hal 109-118

[7] Latief, M. 2009. PenelitianPengembangan. Malang: UniversitasNegeri Malang

[8] Rochmad.2012. Pengembangan perangkat pembelajaran matematika dengan pendekatan problem-based learning untuk meningkatkan keterampilan higher-order thinking.Unnes Journal of Mathematics EducationResearch, 1(1), hlm. 1-9.

[9] Tati. 2009. Pengembangan Perangkat Pembelajaran Berbasis Kontekstual Pokok Bahasan Turunan di Madrasah Aliyah Negeri 3 Palembang. Jurnal Pendidikan Matematika, Januari Vol.3 No.1. 